\title{
Wetenschap en Wetenschapsbeleid / De Anorexiastrategie als maatschappelijke kwaal : de bedreiging van de homo sapiens in het bedrijfsleven
}

Citation for published version (APA):

Cohen, M. J., \& van Witteloostuijn, A. (1997). Wetenschap en Wetenschapsbeleid / De Anorexiastrategie als maatschappelijke kwaal : de bedreiging van de homo sapiens in het bedrijfsleven. Maastricht University. https://doi.org/10.26481/spe.19970110mc

Document status and date:

Published: 10/01/1997

DOI:

10.26481/spe.19970110mc

Document Version:

Publisher's PDF, also known as Version of record

Please check the document version of this publication:

- A submitted manuscript is the version of the article upon submission and before peer-review. There can be important differences between the submitted version and the official published version of record.

People interested in the research are advised to contact the author for the final version of the publication, or visit the DOI to the publisher's website.

- The final author version and the galley proof are versions of the publication after peer review.

- The final published version features the final layout of the paper including the volume, issue and page numbers.

Link to publication

\footnotetext{
General rights rights.

- You may freely distribute the URL identifying the publication in the public portal. please follow below link for the End User Agreement:

www.umlib.nl/taverne-license

Take down policy

If you believe that this document breaches copyright please contact us at:

repository@maastrichtuniversity.nl

providing details and we will investigate your claim.
}

Copyright and moral rights for the publications made accessible in the public portal are retained by the authors and/or other copyright owners and it is a condition of accessing publications that users recognise and abide by the legal requirements associated with these

- Users may download and print one copy of any publication from the public portal for the purpose of private study or research.

- You may not further distribute the material or use it for any profit-making activity or commercial gain

If the publication is distributed under the terms of Article 25fa of the Dutch Copyright Act, indicated by the "Taverne" license above, 
Universiteltsbibllotheek

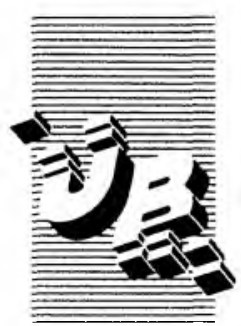

De uitleentermijn verstrijkt op:

\section{MAART 1997}

17 JAit. 2001

Ri|ksuniversiteit Limburg

Postbus 616

6200 MO Maastrucht

Gelieve deze publicatie tijdig te retourneren of (telefonisch) verlenging van de uitleentermijn aan te vragen.

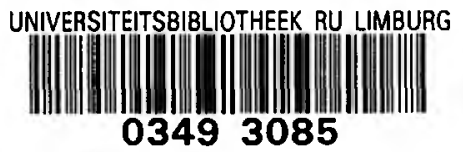




\section{Wetenschap en wetenschapsbeleid}

Toespraak ter gelegenheid van de eenentwintigste dies van de Universiteit Maastricht uitgesproken op vrijdag 10 januari 1997

Prof. mr. M.J. Cohen

Bij twee gelegenheden bezoeken Rectoren de dies van een zusteruniversiteit: bij een lustrum en bij een wisseling van het rectoraat. Op die regel worden slechts weinig uitzonderingen gemaakt. Een ervan is dat de dies van twee universiteiten op dezelfde dag valt. Dat is vandaag het geval nu de Technische Universiteit Delft haar 31e lustrum viert, en wij onze 21e dies. Ik moet daarom vanuit de verte de Delftenaren geluk wensen, en vanuit de verte toezien hoe mijn collega Wakker het rectoraat overdraagt. Gelukkig is Hans Philipsen namens de Universiteit Maastricht present; reden voor zijn afwezigheid hier vandaag.

Bij universitaire lustra plegen eredoctoraten uitgereikt te worden als teken van de hoogste academische eer. Dat was ook het geval toen afgelopen november de Universiteit Twente bij gelegenheid van het zesde lustrum vier eredoctoraten uitreikte. Ik behoorde, zoals uit het voorafgaande moge blijken, tot de aanwezigen. Het was, zoals zo vaak, een inspirerende gebeurtenis: vier erepromotoren die met groot respect aan het auditorium uiteen zetten waarom deze geleerden de hoogste academische eer waardig werden geacht.

Onder deze vier was er én die op mij om verschillende redenen grote indruk maakte. Het ging om een eredoctoraat voor Roger Needham, verbonden aan Cambridge University. Erepromotor was prof. Sape Mullender, het vakgebied -waar ik niets van afweet- de informatica. De laudatio van Mullender was niet alleen buitengewoon geestig, maar liet ook in een notedop zien hoe wetenschap moet worden bedreven. Ik geef $u$ een paar citaten uit Mullenders verhaal, dat ik per e-mail ontving: zonder Needham was dat geloof ik allemaal veel minder gemakkelijk geweest. 
Needham schrijft een deel van zijn succes toe aan serendipiteit: het vermogen om verschijnselen waarnaar je niet op zoek bent, als belangrijk te herkennen, zoals Rob Reneman het begrip enkele jaren geleden in zijn

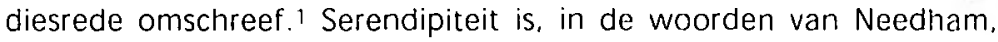
"looking for a needle in a hay stack and finding the farmers daughter". Maar, aldus Mullender, "het is te gemakkelijk om Needham's succes alleen maar toe te schrijven aan het feit dat hij toevallig op het juiste moment op de juiste plaats is geweest. We verkeren allemaal wel eens in die omstandigheid, maar we realiseren ons dat dan niet. En als we het ons later realiseren, dan is het te laat. Ik weiger om te geloven dat Needham alleen maar het geluk heeft gehad om tegen verschillende belangrijke problemen aan te lopen en ze op te lossen voordat anderen zich zelfs maar realiseerden dat het problemen waren. Hij is nooit op zoek geweest naar de naald in die hooiberg, hij zocht de hele tijd die dochter."

Daarna vertelt Mullender dat hij Needham voor het eerst ontmoette in het begin van de jaren tachtig. terwijl hij werkte aan zijn proefschrift. Hij was zeer onder de indruk om zo'n gigant in computer science te ontmoeten. "Maar hij bleek helemaal niet intimiderend, en hij nodigde me onmiddellijk uit om mee te gaan naar die heilige plaats waar hij veel van zijn beste onderzoek deed - de pub."

"Later ontdekte ik", aldus nog steeds Mullender, "de wezenlijke functie van dit dagelijkse uurtje in The Eagle (dat is de naam van de pub). De hele systems research groep, zowel de staf als de studenten, drinkt daar samen een biertje (soms meer dan een of twee). Daar worden de voortgang van het werk en de frustraties van de dag besproken door een groep buitengewoon begaafde mensen; het lijkt wel toverij, maar in die pub zijn een aantal buitengewoon slimme ideeën geboren."

Er zijn vier dingen die mij in de toespraak van Mullender aanspraken. In de eerste plaats natuurlijk de treffende omschrijving van het begrip serendipiteit, een begrip dat zo wezenlijk is, wanneer wij het over het belang van fundamenteel onderzoek hebben. Het belang van dat begrip willen beleidsmakers nog wel eens over het hoofd zien. In de tweede plaats roept deze beschrijving van de groep rond Needham een beeld op van gedreven enthousiasme, een beeld dat zo kenmerkend kan zijn voor 
onderzoek en onderzoekers. Mensen die niets liever willen dan zich laten meeslepen door de wetenschappelijke problemen waar ze zich aan wijden, ondanks de teleurstellingen en frustraties die ze dagelijks meemaken omdat het werk niet gaat zoals het zou moeten gaan, omdat proeven mislukken, gedachten niet kloppen, tegenwerpingen sterker blijken dan zij hoopten. Maar haast altijd met groot enthousiasme, die innerlijke drijfveer die de dagelijkse samenkomst in die pub ook zo goed voorstelbaar maakt. Dat is tegelijkertijd mijn derde punt: onderzoek is groepswerk, steeds meer. Natuurlijk niet altijd: Huizinga kon zijn Herfsttij der Middeleeuwen zonder iemand te raadplegen schrijven op zijn studeerkamer. Maar zelfs in alfa-wetenschappen wordt samenwerking steeds belangrijker; je ziet het voor je, daar in die pub, van die nonsensepraatjes afgewisseld met de ervaringen van de dag, die én van de aanwezigen opeens op een idee brengt dat meestal tot niets leidt. maar soms tot iets bijzonders. Dat zijn dan die ideeèn waar Mullender het over heeft. En dan mijn laatste observatie: groepswerk vindt plaats bij de gratie van wetenschappelijk leiderschap. De wijze waarop Mullender Needham beschrijft, getuigt van zijn oprechte erkenning van en waardering voor de wetenschappelijke autoriteit van Needham. Ook dat zie je in die pub voor je; iedereen bij elkaar, maar wel met de baas als vanzelfsprekend middelpunt, om de eenvoudige reden dat het zo vaak interessant kan wezen wat hij vertelt.

Dames en heren,

Er lijkt geen groter verschil te bestaan tussen dit inkijkje in de microwereld van de wetenschap en een inkijkje in de macro-wereld van het wetenschapsbeleid. Daarover wordt gerapporteerd in het zgn. Wetenschapsbudget, dat is de beleidsnotitie van de Minister van OCW over het te voeren wetenschapsbeleid. Het is als het ware het HOOP voor de wetenschap, en de jongste uitgave ervan verscheen afgelopen september. Als je de geschiedenis van Needham hoort, dan vraag je je af: waarom is wetenschapsbeleid in godsnaam nodig? Zet een aantal begaafde onderzoekers bij elkaar, en laat die vooral hun gang gaan. Daar komt vast wel iets moois uit; natuurlijk, niet altijd, want mislukkingen zijn onvermijdelijk. Kan je op dit terrein sturen, en dan ook nog op een zinvolle manier?

Voor een deel kan dat natuurlijk niet, en is dat ook helemaal niet nodig. Kijk opnieuw naar Needham, of naar tal van andere onderzoekers: 
die moet je niet eens willen sturen. Je moet eenvoudigweg heel tevreden zijn dat zulke onderzoekers er zijn, en je moet ze hun gang laten gaan. Maar dan komen er toch snel een paar vragen op: wat betekent dat precies: hun gang laten gaan? Betekent dat bijvoorbeeld dat ze de beschikking moeten hebben over de financiën die ze voor hun werk zeggen nodig te hebben? Dat, zo leert de ervaring, is niet echt mogelijk, want onderzoekers hebben vrijwel altijd gebrek aan geld, ${ }^{2}$ en het honoreren van hun wensen gaat dus ten koste van onderzoek van anderen. En dat roept de vraag op hoe te kiezen tussen onderzoek. Moet je alleen maar letten op kwaliteit, of is er ook nog zoiets als maat schappelijk belang van onderzoek? En waar moet je eigenlijk meer op letten: op kwaliteit of op belang van onderzoek, of op kwaliteit van de onderzoeker? En is het ook mogelijk de kwaliteit van onderzoek te verbeteren door de organisatie ervan goed in te richten?

Het zijn dit soort vragen die ten grondslag liggen aan wetenschapsbeleid, en dus aan het Wetenschapsbudget. Het plan dat dit jaar is verschenen, is om verschillende redenen interessant. Zo bevat het de reactie van de Minister op het eindrapport van de Overleg Commissie Verkenningen (OCV). Dat is een door hem een aantal jaren geleden ingestelde commissie die bedoeld was om onderzoekers zelf voorstellen te laten doen welke onderwerpen zich in verband met hun maatschappelijke belang lenen om te bewerken. Het interessante van het eindrapport van de OCV en van de reactie van de minister daarop is dat het een geslaagde poging is om de wensen van de politiek met de inzichten van onderzoekers in verband te brengen. Waar vaak geklaagd wordt over de afstand tussen politiek en wetenschap, is hier echt geprobeerd om die afstand te overbruggen. Ook wij zullen ons binnen deze universiteit erop toeleggen om verschillende thema's die ons aanspreken en waarop wij expertise bezitten, te bewerken.

Het Wetenschapsbudget handelt verder voor een belangrijk deel over de organisatie van onderzoek, waarbij voortdurend de vraag aan de orde is hoe de kwaliteit van onderzoek in ons land verder verbeterd kan worden. Het beleid tot vorming van onderzoekscholen, zo'n zeven jaar geleden bij het aantreden van minister Ritzen ingezet, is daarbij in verschillende opzichten van belang geweest. Het heeft de opleiding van jonge onderzoekers gestructureerd en in aanzienlijke mate verbeterd en 
het heeft de kwaliteit van het onderzoek door de bundeling ervan en door een redelijk scherpe selectie van onderzoekers op een hoger plan gebracht. Diegenen die desalniettemin vinden dat dat beleid mislukt is, "omdat het onmogelijk is dat zo'n klein landje als Nederland honderd top-onderzoekscholen zou hebben", miskennen het beoogde doel van de oorspronkelijke operatie: het organiseren van de onderzoekersopleiding en het samenbrengen van goede onderzoekers. Dat doel is goeddeels geslaagd en biedt een goed uitgangspunt om je vervolgens te beraden over de vraag of het onderzoekslandschap inmiddels voldoende toppen kent, en bij ontkennende beantwoording van die vraag. hoe die te realiseren. Wie de voornemens van de Minister met betrekking tot de verdere voortgang van onderzoekscholen beziet, mag concluderen dat hij over die "toppen" blijkbaar niet tevreden is. Hij ontwikkelt in het Wetenschapsbudget verschillende voorstellen om toponderzoek te stimuleren. De eerste is de zgn. dieptestrategie, die beoogt om in de komende tijd een tiental onderzoekscholen aan te wijzen die moeten uitgroeien tot werkelijke centres of excellence, met daarbij behorende financiering die het budget van de desbetreffende scholen wel eens zou kunnen verdubbelen.

Op die voorstellen is, naar mijn smaak terecht, nogal wat kritiek geleverd. Zo rijst de vraag of het wel verstandig is opnieuw een instrument aan de al bestaande stimulansen toe te voegen om de concurrentie onder onderzoekers, en daarmee de kwaliteit van onderzoek te stimuleren. De afgelopen jaren heeft NWO, de Nederlandse Organisatie voor Wetenschappelijk Onderzoek en daarmee de voor die taak geëigende instelling, al een aantal programma's in het leven geroepen die even zo vele stimulansen zijn. Ik wijs op het PIONIER-programma, dat briljante onderzoekers jonger dan veertig jaar in staat stelt onderzoeksteams samen te stellen en nieuwe onderzoekslijnen uit te zetten, en op het SPINOZA-programma dat internationaal erkende onderzoekers tot 55 jaar in staat stelt hun onderzoek te doen met een forse hoeveelheid extra middelen. ${ }^{3}$ Ligt het niet meer in de rede om bij deze middelen aan te sluiten? Het heeft bovendien het voordeel dat groepen van kleinere omvang, veelal gegroepeerd rondom bijzondere onderzoekers -vgl. Needham-, en in hun geheel zeer sterk, door die uitverkiezing de erkenning krijgen die ze verdienen. Een erkenning die bovendien tijdgebonden is, en dus elke keer weer opnieuw waar gemaakt moet worden. Dat lijkt mij beter dan opnieuw een heel circus in het leven te roepen waarin van hele onderzoeksscholen wordt bepaald of ze tot de "top-tien" behoren, 
onderzoeksscholen, die vaak veel omvangrijker zijn dan aparte onderzoeksgroepen, en die daarom in hun geheel niet allemaal even bijzonder kunnen zijn als de verschillende onderdelen. Trouwens, waarom in totaal niet meer dan tien van deze centres of excellence op zo geheel uiteenlopende terreinen als de sterrenkunde en de natuurkunde (die blijkens een net gepubliceerd rapport van een internationale visitatiecommissie op onderdelen van wereldfaam zijn), de geneeskunde, de geesteswetenschappen of de sociale wetenschappen, die vaak ook zeer goed beoordeeld zijn? Waarom tien? Waarom niet twaalf, of twintig? Omdat het geen realistisch perspectief is om te veronderstellen dat meer dan tien tot de absolute top behoort, zoals de minister meent? Tien is een raar getal, zoals ieder getal hier raar zou zijn. Het aantal kan imers nooit gerelateerd zijn aan datgene waar het om gaat: de erkenning van zeer bijzondere kwaliteit, een erkenning die alleen maar kan plaatsvinden binnen de contekst van de desbetreffende wetenschap zelve. Ik zei al dat aan deze "top-scholen" forse extra budgetten worden toegedacht. budgetten die de omvang van die scholen wel eens zouden kunnen verdubbelen. Ook op dat punt heb ik aarzelingen: draagt een zodanige extra toevloed van middelen werkelijk bij aan de kwaliteit? Staat het vast dat dat een betere besteding van onderzoeksgelden is dan een andere aanwending? Kortom, ik ben geen voorstander van dieptestrategie in deze vorm. Ik vind het opnieuw een vermenging van doelen voor onderzoeksscholen: enerzijds het maken van goede onderzoekersopleidingen in een goede wetenschappelijke omgeving, en anderzijds het identificeren van toptalent. Laten wij voor dat laatste niet de onderzoeksscholen gebruiken, maar de instrumenten die NWO daarvoor heeft ontwikkeld en ongetwijfeld verder zal ontwikkelen.

Naast deze dieptestrategie stelt de minister ook een zogenaamde breedtestrategie voor: hij wil dat binnen de middelen die de universiteiten via de zgn. eerste geldstroom, dus rechtstreeks via hem, krijgen, geld speciaal wordt toegewezen voor het "toponderzoek van morgen", dat wil zeggen voor nu al veelbelovende onderzoekscholen, die met extra middelen van nog hogere kwaliteit kunnen worden, daarmee als het ware in de breedte de kwaliteit van het onderzoek verhogend. De universiteitsbesturen kunnen zelf voorstellen doen om welke scholen het gaat, maar hun oordeel moet getoetst worden door NWO. Ook bij dat voorstel heb ik vragen. NWO beheert zoals bekend de tweede geldstroom, dat is de geldstroom die wordt uitgekeerd op basis van in ieder geval kwalitatieve en vervolgens deels ook maatschappelijke overwe- 
gingen. Wij voeren in ons land al jaren lang een discussie over de vraag of die tweede geldstroom niet vergroot zou moeten worden. Niet onbelangrijk argument daarbij is de internationale vergelijking: in zeer veel andere landen is de tweede geldstroom relatief omvangrijker dan in ons land. Dat betekent in de praktijk dat de onderzoeksmiddelen in ons land in relatief hoge mate "vrij" besteed kunnen worden, dus zonder externe kwalitatieve toets vooraf, en omgekeerd, dat door de relatief beperkte middelen NWO lang niet al het onderzoek kan financieren dat daar uit kwalitatieve overwegingen wel voor in aanmerking komt." Dat werkt contraproduktief, want onderzoekers die maar weinig kans hebben om voor NWO-financiering in aanmerking te komen, hebben er lang niet altijd de tijd en moeite voor over hun projecten bij NWO in te dienen.

Ik vind deze poging van de minister, die in het verleden wel eens vaker heeft geprobeerd om de tweede geldstroom te vergroten niet erg geslaagd, omdat zijn voorstel leidt tot een vermenging van eerste en tweede geldstroom, en dus tot minder grote helderheid tussen die geldstromen. ${ }^{5} \mathrm{lk}$ zou er daarom meer voor voelen om. wanneer hij een groei van de tweede geldstroom ten koste van de eerste wenselijk acht, die te realiseren met behulp van een overgangsperiode. Laat hij bepalen welk deel van de eerste geldstroom per universiteit hij wenst over te hevelen van de eerste naar de tweede geldstroom, en laat hij bepalen dat NWO gedurende die overgangsperiode het desbetreffende gedeelte bij de desbetreffende universiteit besteedt. Geleidelijk of na afloop van de vastgestelde periode vervalt dan de verplichting van NWO om het geld bij de desbetreffende instelling te besteden.

Bij dat voorstel passen twee kanttekeningen. De eerste is dat NWO dan wel zo georganiseerd moet zijn dat de verschillende wetenschapsgebieden op een behoorlijke wijze en met voldoende gezag bediend kunnen worden. Dat vergt voortgaande herstructurering van NWO, iets waar de organisatie overigens mee bezig is, en waarvan natuurlijk wel vaststaat dat dat geen eenvoudige zaak is: dat is het trouwens nooit, wanneer er belangen op het spel staan.

Mijn tweede kanttekening heeft betrekking op de positie van de UM. Die is wat de tweede geldstroom betreft niet ijzersterk. Voor een deel ligt dat aan de wetenschapsgebieden die hier beoefend worden. Dat zijn vaak net gebieden, zoals rechtsgeleerdheid en economie, die binnen NWO onderbedeeld zijn, terwij! terreinen als de natuurwetenschappen. 
binnen NWO fors vertegenwoordigd, bij ons juist maar in zeer beperkte mate voorkomen. Het zijn ook net de terreinen waar werken in meer omvangrijke projekten nog maar een uiterst beperkte traditie heeft.

Maar voor een deel komt het ook door onze jeugd. Is die voor het onderwijs ongetwijfeld ais een voordeel te bestempelen, voor onderzoek is - afgezien van de moderne organisatievormen die wij vanaf het begin gekozen hebben- het tegendeel het geval: het kost nu eenmaal tijd om onderzoeksgroepen samen te stellen, die van goede onderzoeksprogramma's te voorzien en in uitvoering te nemen. Wat dat betreft is de gedachte om de tweede geldstroom ten koste van de eerste te versterken, vanuit het perspectief van de UM, mogelijkerwijs bedreigend. Ik zou daartegenover willen stellen dat de kwaliteit van het onderzoek dat hier uitgevoerd wordt, zodanig is dat wij die competitie aan moeten kunnen en durven: de resultaten van onderzoeksvisitaties bieden daarvoor voldoende perspectief .

Dames erl heren.

Het wordt tijd om de beide delen van mijn betoog aan elkaar te knopen. Wetenschapsbeleid is nodig en onontkoombaar, niet alleen om voorwaarden te scheppen voor het verrichten van zo goed mogelijk onderzoek, maar evenzeer om onderzoekers in de gelegenheid te stellen hun werk goed en met enthousiasme te doen. Het wetenschapsbeleid van de afgelopen en van de komende jaren staat daarbij in het teken van toenemende competitie. Het is erop gericht ieders kwaliteit tot de grenzen van het mogelijke te benutten. Dat is prima. Maar wij moeten daarbij wel beseffen -misschien iets meer dan in het Wetenschapsbudget gebeurt, dat wel erg sterk is gericht op "top" en "toponderzoek"- dat "de top" alleen maar kan bestaan bij de gratie van een basis: want zonder basis is er geen top. Onderzoekers als Needham zijn die top, maar zonder zijn makkers in The Eagle is hij nergens. Wanneer wij topprestaties met het respect behandelen dat zo fraai door Mullender werd verwoord. en wanneer de "toppers" dezelfde vanzelfsprekende kameraadschap tentoon spreiden als Needham die een jonge onderzoeker voor het eerst ontmoet, een kameraadschap die voortkomt uit het gedeelde enthousiasme voor gemeenschappelijke wetenschappelijke problemen, dan is dat de sfeer waarin onderzoek het best gedijt; zeker. in concurrentie met anderen, maar wèl met vuur, met gedrevenheid en met plezier. 
$1 \quad$ R.S. Reneman, Hel wetenschappelijk onderzoek in de jaren negentig. Zijn we op de gocde weg?. Rede ter gelegenheid van de zeventiende dies van de RL,Maastricht, 1993, p. 11 .

2 Ik ken er én die tevreden is met wat hij heef, en dat ook keer op keer in het openbaar zegt.

3 Ik ontleen deze formuleringen aan teksten van NWO zelf; vlg. Appendix 23 van NWO: the first seven years, te vinden in het Report of the NWO cvaluation committec. juni 1996.

4 Dat is overigens niet de enige reden; NWO is tot op heden niet altijd even sterk geweest in het verdelen van de aanwezige middelen over de verschillende disciplines.

5 De ATW heeft in een behartigenswaardige reactie op het Wetenschapsbudget eveneens op dit gevaar gewezen. 
10 


\section{De Anorexiastrategie als maatschappelijke kwaal}

De bedreiging van de homo sapiens in het bedrijfsleven

\section{Eenentwintigste Dies Natalis}

\section{7}

Prof. dr. A. van Witteloostuijn

Hoogleraar bedrijfseconomie en bedrijfskunde, i.h.b. organisatie

Decaan van de Faculteit der Economische Wetenschappen en Bedrijfskunde

"Timmer af. Boonstra neemt het roer over en zegt: we hebben nu al vijf kwartalen de resultaten zien dalen, wij/jullie managers dragen de schuld (zijn financiële collega maakte die managers zelfs uit voor rotte vis). Daar zit je dan als - wederom - bedreigde soort." (Leo Groosman in het NRC Handelsblad van maandag 28 oktober 1996: 9).

"Steeds meer Amerikanen ontdekken in hun directe omgeving dat werknemers na jaren van trouwe dienst door een florerend bedriff aan de kant gezet kunnen worden, met als enige reden dat een nieuwe ontslagronde is aangebroken in de vrijwel permanente reorganisatie die in veel organisaties woedt." (Juurd Eijsvoogel in het NRC Handelsblad van zaterdag 2 november 1996: 19). 


\title{
Mijnheer de rector magnificus,
}

\author{
Dames en heren,
}

1

Twee citaten uit de herfst van 1996 met dezelfde boodschap: het gaat slecht met de menselijke soort in organisaties.' Philips' voorman Boonstra wijt de dalende resultaten van de winstgevende mammoetonderneming aan het management, terwijl iedere Amerikaan wel iemand kent die het slachtoffer is geworden van een sanering van een gezond bedrijf. De rij van reorganiserende winstmakers die het nieuws halen, is enorm: de KLM. Shell en Unilever is een ander drietal aansprekende voorbeelden van ondernemingen die drastische saneringen hebben aangekondigd. President-directeur Bouw van de KLM gaat (weer) fors snijden in het management (NRC Handelsblad van maandag 4 november 1996: 11). Shell-topman Herkströter zweert bij TINA (There is No Alternative in het NRC Handelsblad van zaterdag 16 november 1996: 17), en de tijd dat Unilever niet saneerde kan slechts de vijftigplusser zich nog herinneren. Aankondigingen van reorganisaties - een eufemisme voor saneringen - halen vaak zelfs het nieuws niet. Daarvoor is deze bekende weg niet langer nieuw genoeg.

Deze golf van voortdurende saneringen wordt verdedigd met een verwijzing naar de mondiale concurrenten die ook gehoor geven aan de noodzaak modern te blijven - dat wil zeggen: efficiënt en flexibel, en daarom geautomatiseerd. In consulententaal: mean and lean. Het nieuwste panacee in deze context is machomanagement. In het NRC Handelsblad van 26 oktober 1996 is een artikel op de voorpagina voorzien van een typische kop: 'de beul rukt op in managersland'. Deze beul saneert niet alleen op de werkvloer, maar ook (in) het middenkader. 'Verplatting', afslanking en uitbesteding zijn het credo - dat alles ten dienste van de winstgevendheid en dus de aandeelhouder. Daarmee zijn werknemers, inclusief de managers zelf, een bedreigde soort geworden.? Een tot in het oneindige groeiende omzet per steeds schaarser wordende werknemer - daar gaat het allemaal om. De manager en werknemer moeten sneller, beter, electronischer en flexibeler worden. Dat is sinds jaren het geval in Zuid-Oost Azië en Noord-Amerika, en Europa en Nederland kunnen niet achterbljjen. Kortom: de mondialisering. verder versterkt door technologische ontwikkelingen, slaat keihard toe. 
In deze rede wordt de vraag gesteld in hoeverre met deze status van permanente reorganisatie van het mondiale en Nederlandse bedrijfsleven het paard achter de wagen wordt gespannen. Moet de bedreigde werknemer zich inderdaad terugtrekken in zijn reservaat van vrije tijd, of werkt deze verbanning contraproductief? Nog een waarschuwing vooraf. Normaal gesproken placht ik mijn gehoor af te leiden van de inhoud van mijn betoog via de nodige dynamiek - laat ik zeggen: muziek en dans. In deze plechtige omgeving kan daarvan helaas geen sprake zijn. $U$ zult het dus moeten doen met mijn sonore stemgeluid en Zalmiaanse mimiek. Een kleine troost: het gaat slechts een half uur duren.

\section{2}

Een onontkoombare conclusie dringt zich op: het gaat slecht met het Nederlandse bedrijfsleven. ${ }^{3}$ Dat kan niet anders: de ene sanering volgt immers op de andere. De voorbeelden van het volgende vijftal beroemde saneerders in de jaren negentig spreken voor zichzelf: ABN Amro, KLM, Philips, Shell en Unilever. ${ }^{4}$ Dat de bankwereld noodlijdend is weet iedereen. ABN Amro heeft daarom het aantal werknemers in Nederland laten dalen van ruim 40 duizend in 1990 naar nog geen 35 duizend in 1995. De mondiale omzet per werknemer is gestegen van bijna 5,5 miljoen gulden in 1990 naar ruim 8 miljoen gulden in 1995. Het gevolg hiervan is een geaccumuleerd bedrijfsresultaat in de periode 1990-1995 van ruim 25 miljard gulden. KLM-voorzitter Bouw heeft laten weten dat het roer om moet: uitbesteding - en dus afslanking - is het nieuwe motto. zodat het geaccumuleerde bedrijfsresultaat van ruim 1,5 miljard gulden in de eerste helft van de jaren negentig zal verbleken bij wat de tweede helft van het fin de siecle gaat opleveren. Ook de stijging van de omzet per werknemer van bljna 230 duizend gulden in 1990 tot ruim 330 duizend gulden in 1995 moet verder worden versneld. De boodschap van het Philips-management moet ongeveer de volgende zijn: ondanks het afvloeien van bijna 10 duizend Philips-getrouwen sinds 1990, met weer een geringe groei in de laatste jaren, is het geaccumuleerde bedrijfsresultaat van Philips slechts een dikke 12 miljard gulden, met een teleurstellende groei van de omzet per werknemer van bijna 195 duizend gulden in 1990 tot ongeveer 245 duizend gulden in 1995. Shell is het zieligste jongetje uit de klas der mammoetsaneerders met een geaccumuleerd bedrijfsresultaat van ruim 88 miljard gulden en een productiviteit die is gestegen van een omzet van ruim 433 duizend 
gulden per werknemer in 1990 tot bijna 670 duizend gulden per werknemer in 1995.5 Ook de Shell-top vindt dat het zo niet langer kan: het afvloeien van personeel is een must, omdat de daling van 137 duizend werknemers in 1990 tot 104 duizend in 1995 niet toereikend is. Bij Unilever is weinig veranderd: 304 duizend werknemers in 1990 tegen 308 duizend in 1995. Het geaccumuieerde bedrijfsresultaat is bijna 40 miljard gulden, met een lichte stijging van de omzet per werknemer van ruim 240 duizend gulden in 1990 naar 260 duizend gulden in 1995. Toch heeft ook de nieuwe Unilever-topman FitzGerald ingrijpende afslankingen aangekondigd.

In de Zuidlimburgse regio heeft hetzelfde reorganisatievirus pijnlijk toegeslagen. Het bekende troika DSM, KNP BT en Sphinx is illustratief. DSM kan wijzen op een geaccumuleerd bedrijfsresultaat in 1990-1995 van ruim 4 miljard gulden. Het aantal werkzame personen is afgenomen van ongeveer 24 duizend in 1990 tot plusminus 17 duizend in 1995, met een stijging van de omzet per werknemer van 374 duizend gulden in 1990 tot bijna 574 duizend gulden in 1995. Het Maastrichtse KNP is in 1991 opgegaan in KNP BT. De daarop volgende periode (vanaf 1992) heeft een geaccumuleerd bedrijfsresultaat opgeleverd van ruim 10 miljard gulden. Het aantal werkzame personen is licht gestegen van bijna 27 duizend tot ruim 28 duizend, met een toenemende productiviteit van 440 duizend gulden omzet per werknemer in 1992 tot 525 duizend gulden in 1995. Sphinx is begin 1993 samengegaan met het Zweedse Gustavsberg. Sindsdien is het geaccumuleerde bedrijfsresultaat opgelopen tot 152 miljoen gulden. Het aantal werknemers is afgenomen van 3.969 in 1993 tot 3.879 in 1995. met een stijging van de omzet per werknemer van ruim 203 duizend gulden in 1993 tot bijna 215 duizend gulden in 1995 .

Ook de ontwikkeling van de werkgelegenheid in de bijbehorende bedrijfstakken spreekt boekdelen. Het aantal werkzame personen in de nijverheid is teruggelopen van boven de 1.5 miljoen in 1990 naar onder de 1.5 miljoen in 1995. Een typisch voorbeeld van een sanerende industriële bedrijfstak is de chemie. De werkgelegenheid in de chemische industrie (inclusief rubber en kunststoffen) is teruggelopen van ongeveer 121 duizend in 1990 tot nog geen 109 duizend in 1993. De banengroei in de dienstensector is nauwelijks voldoende om de werkgelegenheid op peil te houden, met een stijging van bijna 4.1 miljoen werkzame personen in 1990 tot 4,2 miljoen in 1994. Het gevolg van beide ontwikkelingen is dat de werkgelegenheid in de particuliere sector nagenoeg constant blijft. Ook in de dienstenmarkten heeft het reorganisatievirus zijn entree gevierd. Naast de financiële dienstverlener ABN Amro zijn de 
detaithandelonderneming Vendex en het transportbedrijf Nedlloyd illustratieve voorbeelden. Vendex heeft de omzet per werknemer zien stijgen van ruim 120 duizend gulden per werknemer in 1990 tot bijna 132 duizend guiden in 1995, met een reductie van het aantal werknemers van ruim 89 duizend in 1990 tot bijna 86 duizend in 1995 en een geaccumuleerd bedrijfsresultaat van boven de 1,7 miljard gulden. Nedlloyd heeft het aantal werknemers teruggebracht van ruim 26 duizend in 1990 tot ongeveer 18.5 duizend in 1995, met een gelijktijdige toeneming van de productiviteit van ongeveer 256 duizend gulden omzet per werknemer in 1990 tot plusminus 366 duizend in 1995. Het geaccumuleerde bedrijfsresultaat is ruim 481 miljoen gulden.

\section{3}

Het geaccumuleerde bedrijfsresultaat van de vijf vooraanstaande nationale saneerders is ruim 166 miljard gulden, met een daling van de gezamenlijke werkgelegenheid van ruim 800 duizend in 1990 tot net 772 duizend in 1995.6 Het beeld is hetzelfde voor het Zuidlimburgse trio in de periode 1992-1995: het gezamenlijke geaccumuleerde bedrijfsresultaat is ruim 10 miljard gulden, met een daling van het aantal werkzame personen van bijna 53 duizend in 1992 tot nog geen 50 duizend in 1995. De gezamenlijke werkgelegenheid van de tien bedrijven is gedaald van bijna 1.2 miljoen in 1990 tot ruim een miljoen in 1995, met een totale accumulatie van het bedrijfsresultaat tot bijna 180 miljard gulden. Deze duale ontwikkeling is schrijnend: hoge geaccumuleerde bedrijfsresultaten gaan hand in hand met een dalende werkgelegenheid. ${ }^{7}$

De tien voorbeelden van grote ondernemingen hoeven natuurlijk niet representatief te zijn. In dit verband kan worden gewezen op andere grote ondernemingen die een andere koers hebben gevaren, of de banendynamiek in het midden- en kleinbedrijf. De grootgrutter Ahold heeft bij voorbeeld het personeelsbestand licht laten groeien van 304 duizend in 1990 tot 308 duizend in 1995, met een geaccumuleerd bedrijfsresultaat van bijna 3.7 miljard gulden en een toenemende productiviteit van bijna 317 duizend gulden omzet per werknemer in 1990 tot plusminus 351 duizend gulden in 1995. Een belangrijke vraag is daarom: wat valt in deze context op te merken over de ontwikkeling van de Nederlandse economie als geheel? In dezelfde periode 1990 tot en met 1995 is het bruto binnenlands product (tegen marktprijzen) met ongeveer $30 \%$ gestegen van ongeveer 457 miljard gulden in 1990 tot 
ruim 561 miljard gulden in 1995. In deze zelfde periode is de werkgelegenheid licht toegenomen van ruim 5.5 miljoen naar 5.8 miljoen werkenden. ${ }^{8}$ Deze stijging is echter niet voldoende geweest om de groei van de beroepsbevolking van bijna 6 miljoen in 1990 tol plusminus 6.4 miljoen in 1995 te kunnen bijhouden. Het saldoresultat is een toeneming van het aantal Nederlanders met een werkloosheid- of bijstanduitkering van 794 duizend in 1990 tot ruim een miljoen in 1995. Daarnaast ontvingen, zowel in 1990 als in 1995, circa 1.6 miljoen Nederlanders een uitkering vanwege ziekte, de WAO, de VUT of de AWW. Het totale aantal uitkeringontvangers is derhalve gestegen van ongeveer 2.4 miljoen in 1990 naar bijna 2.6 miljoen in $1995 .{ }^{9}$ in termen van het bruto binnenlands product per werkende is de 'productiviteit' van de Nederlandse economie opgelopen van ruim 8.2 miljoen gulden in 1990 tot boven de 9.6 miljoen gulden in 1995. ${ }^{10}$ De conclusie is duidelijk: ook de Nederlandse economie als geheel is nog altijd driftig aan het saneren.

Deze sanering heeft nog een andere belangrijke consequentie: de tweedeling in de Nederlandse samenleving neemt toe. Niet alleen wordt de groep niet-werkenden nog altijd groter, maar daarnaast worden de uitkeringontvangers steeds armer. "De conclusie is weer onverbiddelijk: de rijken worden rijker, en de armen armer. De econoom Eduard Bomhof vat deze ontwikkeling ais volgt krachtig samen: "De Nederlandse economie is 25 procent sterker dan in 1985, maar de sociale minima hebben ongeveer 25 procent minder vrij te besteden" (NRC Handelsblad van 2 december 1996: 7). En wat misschien nog erger is: de armen voelen zich steeds overbodiger. In dit verband spreekt de socioloog Kees Schuyt van sociale overbodigheid als het grootste probleem van de Nederlandse samenleving (NRC Handelsblad van zaterdag 30 november 1996: 9). Wat heeft het heden te bieden wanneer de toekomst uitzichtloos is? Deze toenemende tweedeling heeft overigens ook voor de werkenden een keerzijde. Van de werkenden wordt immers steeds meer verwacht: zij moeten zich bewijzen als flexibele hardwerkers, of hardwerkende flexwerkers. Waar anders moet de krachtige productiviteitstijging vandaan komen?

$$
4
$$

Bijna tien minuten cijferfetisjisme moet genoeg zijn. Tabellen vertellen is vermoeiend - voor spreker en luisteraar. Daarom is het tijd het 
verhaal achter de getallen voor het voetlicht te brengen. Om te beginnen is de diagnose even triest als eenvoudig: de homo sapiens in het bedrijfsleven staat onder druk. De manager en werknemer als productiefactor hebben het zwaar te verduren. Saneringen en 'verplattingen' zijn schering en inslag. Via permanente reorganisaties zijn veel ondernemingen op zoek naar een voortdurende stijging van de productiviteit per werknemer. Op dit aambeeld der sanering wordt sinds jaar en dag gehamerd door een lange reeks van vooraanstaande managementgoeroes. Twee voorbeelden: Tom Peters pleit voor een slanke personeelsbezetting, terwijl Michael Porter het kostenleiderschap roemt.17 Beide topconsulenten wijzen op de noodzaak van de permanente stijging van de productiviteit van de werknemers. Het is mijn overtuiging dat deze volgehouden anorexiastrategie zelfs vanuit het perspectief van de individuele onderneming niet verstandig is. Anders gezegd: mijn verwachting is dat de voortdurende saneringen uiteindelijk averechts werken. Ik zal u uitleggen waarom.

In zijn recente boek Competitive advantage through people: unleashing the power of the work force (1994, Boston. MA: Harvard Business School Press) bouwt de bekende Amerikaanse organisatiewetenschapper Jeffrey Pfeffer een krachtig pleidooi op voor een grotere aandacht voor de werkvloer. Zijn argument is eenvoudig: uiteindeijk moet de concurrentiekracht van een onderneming worden opgebouwd en onderhouden door de werknemers, met name de werkvloer en het middenkader. Verwaarlozing van het personeel leidt tot afnemende loyaliteit, motivatie en tevredenheid - met alle nadelige gevolgen vandien. Het is daarom verstandig hoge lonen te bieden, veel aan scholing te doen, met lange-termijncontracten te werken, werknemerparticipatie te bevorderen, goede relaties met vakbonden op te bouwen, en aandelen te verstrekken aan het personeel. Met een variant op het bekende credo management by walking around kan dit pleidooi worden getypeerd als management by paying attention. Het is daarom te verwachten dat saneringen averechts zullen werken. In deze context is het frappant dat een recente enquète onder Shell-medewerkers heeft aangetoond dat ruim de helft van het personeel met een lagere motivatie kampt dan een jaar geleden. De conclusie is dat "[d]e reeks reorganisaties die Shell de afgelopen jaren heeft doorgevoerd, ... een demotiverende invloed [heeft] op het personeel van de multinational" (NRC Handelsblad van dinsdag 10 december 1996: 17). Ook met het populaire schrappen van managementlagen - in lelijk Nederlands: verplatten - moet voorzichtig worden omgesprongen. In het boek The knowledge-creating company 
(1995, New York: Oxford University Press) wijzen de Japanners Ikujiro Nonaka en Hirotaka Takeuchi op de sleutelrol die het middenmanagement speett bij het scheppen en instandhouden van het leervermogen van organisaties. Zonder middenkader zal de informatiestroom tussen topmanagement en werkvloer disfunctioneren.

De resultaten van een aantal Maastrichtse onderzoekingen wijzen eveneens op het doorslaggevende belang van personeel en management bij de verklaring van prestatieverschillen tussen ondernemingen. ${ }^{13}$ Twee studies kunnen de teneur van de bevindingen illustreren. In de eerste plaats is in een doorsnede-onderzoek in de Vlaamse meubelindustrie in het jaar 1990 de invloed van de kenmerken van de topmanager op de winstgevenheid van de onderneming onder de loep genomen. Een sleutelresultaat is dat de winstgevenheid van een meubelbedrijf voor een belangrijk deel wordt verklaard door de stimulerende persoonlijkheidskenmerken van de topmanager. Sterker nog: een topmanager met een inspirerende persoonlijkheid kan het zich permiteren voor een minder geschikte strategische koers te kiezen. In de tweede plaats heeft een tijdreeksonderzoek in de Nederlandse accountancymarkt in de periode 1880-1990 zich gericht op de rol van het personeel bij de verklaring van overleving. Een cruciale bevinding is dat een accountancykantoor een hogere kans op overleven heeft naarmate het personeel beter is geschoold. ongeacht de specifieke marktomstandigheden. Kortom: aandacht voor de werving en scholing van het personeel, inclusief het management, draagt in belangrijke mate bij aan de verklaring van het succes van ondernemingen.

Een fraai buitenlands voorbeeld van de contraproductiviteit van een staat van permanente afslanking is de Amerikaanse vliegtuigbouwer McDonnell Douglas Corporation (MDC; zie de beschrijving van Ferry Versteeg in het NRC Handelsblad van donderdag 5 december 1996: 19). MDC heeft een lange en succesvolle historie in de Amerikaanse en mondiale vliegtuigindustrie achter de rug. In 1970 was MDC nog de onbetwiste nummer een in de civiele vliegtuigbouw in de Verenigde Staten, ver voor bij voorbeeld Boeing. In de militaire markt wist MDC deze zelfde toppositie vast te houden tot 1993. Inmiddels is het trotse bedrijf vlak voor het Kerstfeest van 1996 in feite overgenomen door de grote concurrent Boeing (formeel wordt overigens gesproken van een fusie). MDC gaat verder als een divisie van Boeing. In de jaren voor deze trieste afloop heeft MDC in een voortdurende staat van anorexia verkeerd. President John McDonnell, overigens familie van de oprichter. heeft het personeelsbestand binnen een paar jaren gehalveerd tot 
ongeveer 63 duizend werknemers. Deze daling ging gepaard met indrukwekkende productiviteit- en rendementstijgingen. De Newyorkse beurs was dan ook enthousiast: het aandeel MDC heeft in de periode 1992-1996 gouden tijden beleefd. De koers van het MDC-aandeel steeg met 500 procent - dat is ver boven de gemiddelde koersstijging binnen de vliegtuigindustrie -, ondanks dramatische marktaandeelverliezen. Een dergelijke staat van dienst stemt de nieuwe topman Stonecipher uiterst tevreden: "Het maakt me niet uit hoe groot we zijn, zolang we onze winstgevendheid maar vergroten". De afloop is bekend: MDC is niet meer, en Stonecipher wordt de tweede man van het nieuwe Boeing.

Het voorbeeld van McDonnell Douglas Corporation is een prachtige illustratie van de destructieve werking van de nieuwste managementhype: de maximalisatie van de shareholders' value - of, in 'normaal' Nederlands, het maximaliseren van koersstijgingen en dividenduitkeringen. Elke zichzelf respecterende ondernemer laat met de regelmaat van de klok weten dat het uiteindelijke doef van al dat ondernemen is om de aandeelhouder zoveel mogelijk tevreden te stellen. Anders gezegd: de beurs regeert grote delen van economisch Nederland. Naast Cola en de hamburger is dit een belangrijk Amerikaans exportproduct. Mijn standpunt druist volledig in tegen wat momenteel en vogue is in de discussie over een herijking van de Nederlandse governance structure. In het rapport van de commissie-Peters wordt in aansluiting op de Angelsaksische traditie juist gepleit voor een sterke uitbreiding van de invloed van aandeelhouders. In een redactioneel commentaar wordt in het NRC Handelsblad (van zaterdag 2 november 1996: 9) deze mening ondersteund. Frappant is dat in hetzelfde redactionele commentaar wordt verwezen naar grote Europese (Daimler-Benz en Olivetti) en Nederlandse (Bols Wessanen, KNP BT. Philips en Robeco) ondernemingen die onder druk van aandeelhouders aan het saneren zijn geslagen. Het is deze keerzijde van het Angelsaksische systeem die naar mijn mening zwaar wordt onderschat. In dit verband is het opmerkelijk dat Pfeffer (1994) zich juist keert tegen de Angelsaksische dominantie van de aandeelhouder, met een verwijzing naar de in zijn ogen superieure Duitse en Japanse systemen.

De ontwikkeling in de richting van een Angelsaksisch beurssysteem heeft nog een andere schaduwzijde: de tweedeling in de Nederlandse samenleving wordt erdoor versterkt. ${ }^{14}$ Aan de ene kant gaat het beurshandelaren in het algemeen om korte-termijnresultaten. De gemiddelde aandeelhouder is niet geinteresseerd in een langetermijnrelatie met zijn 'eigendom'. maar poogt via de aan- en verkoop 
van zijn aandclenbezit op korte termijn zijn vermogen te versterken via de kapitalisatie van koersstijgingen. Deze korte-termijnoriëntatie van de gemiddelde aandeelhouder slaat uiteraard over op zijn eigendom: de onderneming. De voortdurende zoektocht naar korte-termijnrendementen is een krachtige stimulans voor permanente reorganisaties. Het slachtoffer van reorganisaties is echter veelal de onderkant van de samenleving. ${ }^{15}$ Juist de lager opgeleide werknemer met weinig vaardigheden is niet in staat zich te herstellen van een reorganisatie-ontslag. Aan de andere kant profiteert met name de bovenkant van de samenleving van de dominantie van de beurskrachten. Immers: de gemiddelde aandeelhouder is vermogend. Het effect van deze tweeledige consequentie van de beurscultuur, belichaamd in het nieuwe panacee van shareholders' value maximization, is dat de tweedeling in de Nederlandse samenleving verder wordt verscherpt.

Natuurlijk wijzen de saneerders bij wijze van maatschappelijke verontschuldiging met hun vinger naar de boze buitenwereld. Vooral het koppel automatisering en mondialisering mag zich in deze context in een enorme populariteit verheugen. De harde concurrentiestrijd in de wereld en omstreken, met gebruikmaking van moderne informatie- en productietechnologieën, dwingt het bedrijfsleven ertoe permanent te saneren - het motto is: bijblijven. De anorexiastrategie is een conditio sine qua non om te overleven. Met het voorgaande betoog hoop ik u ervan te hebben overtuigd dat deze argumentatie niet steekhoudend is. Met permanente saneringen snijden ondernemingen niet alleen letterlijk maar ook figuurlijk in hun eigen vlees. Een scherpe diagnose is echter een ding, maar de keuze van adequate geneesmiddelen is een noodzakelijke vervolgstap.

Thomas More publiceerde in 1516 zijn beroemde Utopia - een indrukwekkende schets van de ideale samenleving. Zover kan en wil ik niet gaan in de context van deze diesrede van een half uur. Waar ik mee wil volstaan, is een korte beschrijving van zes deelutopieen die tezamen de genezing van de maatschappelijke anorexiakwaal dichterbij kunnen brengen.

\section{Utopie I:}

spaarzame saneringen. Reorganisaties worden vermeden. Ondernemingen komen tot het besef dat de korte-termijnbaten van saneringen niet opwegen tegen de lange-termijnnadelen. Met perma- 
nente saneringen wordt de concurrentiekracht uiteindelijk ondergraven ten gevolge van de afnemende loyaliteit en motivatie van het personeel. Met management by paying attention worden duurzame concurrentievoordelen behaald, terwijl management by personnel reduction na verloop van tijd slechts averechtse effecten opleverd.

\section{Utopie II:}

herwaardering van het middenmanagement. De rol van het middenmanagement wordt in ere hersteld. Ondernemingen begrijpen dat met het voortdurend schrappen van managementlagen het creatieve vermogen op de werkvloer wordt ondermijnd. Juist het middenkader vormt immers de schakel tussen top-down- en bottom-upprocessen. Zonder deze wederzijdse informatie-uitwisselingen krijgt het leervermogen geen kans om tot ontwikkeling te komen.

\section{Utopie III:}

opbouwen van buffervoorzieningen. Ondernemingen investeren in hun personeel via scholing, lange-termijncontracten, loopbaanplanning en hoge lonen. Bedrijven zien in dat deze voorzieningen een buffer van loyaal en gemotiveerd personeel genereren. Het loyale personeel is in slechte tijden bereid een stap terug te doen. De gemotiveerde werknemers zijn verantwoordelijk voor het ontwikkelen en in uitvoering brengen van nieuwe groei-initiatieven

\section{Utopie IV:}

continentaal beurssysteem. De continentale wereld ziet in dat het Angelsaksische beurssysteem gepaard gaat met teveel perverse effecten. De korte-termijnoriëntatie van de gemiddelde aandeelhouder staat haaks op de lange-termijnvisie die noodzakelijk is voor de duurzame ontwikkeling van ondernemingen. De invloed van de aandeelhouder wordt daarom beperkt. Bedrijven richten zich op duurzame positieverbeteringen in plaats van korte-termijnrendementen.

\section{Utopie V:}

aandelen voor iedereen. Aandelen zijn voor en van iedereen. Het management en personeel delen in de winst via aandelenparticipatie. Ook niet-actieven krijgen aandelen in bezit. Een deel van de betaling van uitkeringen kan bij voorbeeld plaatsvinden in de vorm van aandelen. Hiermee worden management en personeel verder gemotiveerd, en wordt de tweedeling in de samenleving van zijn scherpe kanten ontdaan. 


\section{Utopie VI:}

decentralisatie van uitkeringen. De betaling van uitkeringen is gedecentraliseerd met behoud van wettelijke richtlijnen. Voor een periode van bij voorbeeld twee jaren brengen ondernemingen de uitkeringen van hun ontslagen personeel zelf op. Hier staat uiteraard een reductie van de sociale werkgeverlasten tegenover, zodat ondernemingen - alleen of in bedrijfstakverband - in staat zijn de noodzakclijke fondsvorming te ontwikkelen en op peil te houden.

Deze opsomming van utopieen is alles behalve volledig, en de ene utopie is natuurlijk gemakkelijker te benaderen dan de andere. ${ }^{16}$ Het is vooral te hopen dat het bedrijfsleven tot inkeer komt - in Nederland en daarbuiten. Permanente anorexia kent immers zelden een goede afloop. ook niet voor de ondernemingen zelf.

Mijnheer de rector magnificus.

Dames en heren.

De cirkel is rond. Ik nader het einde van mijn utopisch betoog. De populaire anorexiastrategie is niet alleen een bedreiging voor de homo sapiens in het bedrijfsleven, maar vormt daarnaast een maatschappelijke kwaal. Het maatschappelijke ziektebeeld is ernstig: de teruglopende werkgelegenheid in de particuliere sector tezamen met de toenemende tweedeling in de samenleving vormt een explosieve combinatie. En wat deze duale ontwikkeling van een cynisch accent voorziet: ook voor de ondernemingen zelf werkt de staat van permanente sanering uiteindelijk averechts. Het gevaar is een neerwaartse spiraal van saneringen die leiden tot slechtere resultaten die vervolgens weer nopen tot aanvullende reorganisaties die ... . Ten gevolge van de mondiale concurrentiestrijd worden veel ondernemingen deze vicieuze cirkel ingedreven. Ook hier doet zich het bekende fenomeen voor dat individuale rationaliteit kan leiden tot collectieve rampen. Natuurlijk betekent dit niet dat saneringen nooit noodzakelijk en wenselijk zijn. De huidige praktijk is echter ver verwijderd van de gulden middenweg.

Het slotaccoord bestond uit zes fraaie oplossingen, en evenzoveel utopieën. ${ }^{17}$ Ongetwijfeld roept deze schets bij velen deja-vugevoelens op. De kerk van de gelovigen in de maakbaarheid van de samenleving zat in 
de jaren zestig en zeventig bomvol, maar is sinds de jaren tachtig in hoog tempo leeggeiopen. Zeker sinds de val van de Berlijnse muur is het progressief om het panacee voor alle economische kwalen te zoeken in vrije marktwerking. '"s Natuurlijk is vrije marktwerking belangrijk. Ultra-vrije marktwerking heeft echter evidente keerzijden. Misschien had Karl Marx toch een beetje gelijk. Ik ben zeker geen (neo- of post-) Marxist - integendeel, nooit geweest ook. Maar met het volledig verwerpen van Marx' gedachtengoed wordt het kind met het badwater weggegooid. Slechts met een sociaal gezicht is het kapitalistische systeem rechtvaardig voor de onderkant van de samenteving. Vanuit het moderne vrije-marktperspectief is strategische anorexia geen maatschappelijke kwaal, maar een logisch symptoom van blakende gezondheid. De nieuwe financieeleconomische hoofdstroom binnen de PvdA onderscheidt zich met vergelijkbare vrije-marktfilosofieën nauwelijks van zijn liberale die-hard tegenhanger. Mijn zes oplossingen zijn dus zes conservatieve utopieen. In de bovenkamer van de ivoren toren is naiviteit in de vorm van academische vrijheid echter gelukkig nog geoorloofd. Dromen mag. hoop ik ook in de tweede helft van de jaren negentig.

\section{Samenvatting}

Het ene na het andere krantenbericht over Nederlandse en buitenlandise ondernemingen heeft dezelfde boodschap. het gaat slecht met de menselijke soort in organisaties. Philips' voorman Boonstra wijt de dalende resultaten van de winstgevende mammoetonderneming aan het management, terwijl iedere Amerikaan wel iemand kent die het slachtoffer is geworden van een sanering van een gezond bedrijf. De rij van reorganiserende winstmakers die het nieuws halen, is enorm: KLM, Shell en Unilever is een ander drietal aansprekende voorbeelden. Het nieuwste panacee in deze context is machomanagement. In het NRC Handelsblad van 26 oktober 1996 is een artikel op de voorpagina voorzien van een typische kop: 'de beul rukt op in managersland'. Daarmee zijn werknemers, inclusief de managers zelf, een bedreigde soort geworden. In deze rede wordt de vraag gesteld in hoeverre met deze status van permanente reorganisatie van het mondiale en Nederlandse bedrijfsleven het paard achter de wagen wordt gespannen. Moet de bedreigde werknemer zich inderdaad terugtrekken in zijn reservaat van vrije tijd, of werkt deze verbanning contraproductief? 
De bron van beide citaten is niet toevallig het NRC Handelshlad. Met deze rede beoog ik niet een doorwrochte wetenschappelijke verhandeling af te leveren. Via de ruwe schets van een alutal ontwikkelingen, in de praktijk en in de wetenschap, hoop ik de aandacht te kumen vestigen op een pregnant maatschappelijk fenomeen. Ook om een andere reden zijn de verwijzingen naar de nationale avondkrant overigens niet toevallig: het abonnementtarief wordt elk kwartaal automatisch overgemakt.

2 De biologische metafor van de bedreigde (dier)soort is alles behalve nieuw in de economische wetenschappen. De liefhebber kan an een korte reis door de geschiedenis van het economisch denken veel plezier beleven. De evolutionaire bioloog aller evolutionaire biologen - Charles Darwin - heeft zich naar eigen zeggen (in de introductie van zijn berocmde Origin of species uit 1859) laten inspireren door de econoom Thomas Malthus. Overigens wordt Darwins dankbetuiging aan het adres van Malthus door Joseph Sclumpeter, zelf bekend geworden als evolutionair econoom, sterk gerelativeerd in zijn History of economic inlyysis 11954: $445-446$ (New York: Oxford University Press)l. Een reeks van beroende economen heeft vervolgens een bijdrage geleverd aan de ontwikkeling van een economische evolutietheoric. Een standaardwerk binten deze traditie is An evolutionary theorv of economic change (1982, Cambridge, MA: Harvard University Press) van Richard Nelson en Sidney Winter. Voor een overzicht van moderne evolutionaire benaderingen zie Christophe Boone en Arjen van Witteloostuijn (1995) Industrial organization and organizational ecology: the potentials for cross-fertilization, Organizaltion Sudics (16: 265-298).

In deze en de volgende paragraaf volgen schier cindeloze recksen getallen. Het cijfermateriaal is ontleend aan een rijke variëteit van bronnen. De belangrijkste zijn de jaarverslagen van de genoemde ondernemingen, de Macro-economische verkenningen van het Centraal Planbureau, de Statistische jaartocken en Maandstatistiekcu van het Centraal Bureau voor de Statistiek, en Kengetallen Nedeflandse bmersfondsen van de $A B N$ Amro. Overigens maakt dergelijk spitwerk weer eens duidelijk welke haken en ogen kleven aan vergelijkend tijdrecksonderzoek. Zelfs bimnen dezelfde bron is vaak sprake van ontbrekende informatic en wijzigende definitics. Voor de teneur van het betoog doet deze 'ruis' echter niet ter zake.

De navolgende getallen geven een indicatie van de ontwikkelingen zonder precies te zijn (zie ook noot 3). Met de vermelding van het bedrijfsresultaat worden boekhoudkundige voetangels en -klemmen zoveel mogelijk ontweken. Gemakshalve is de invloed van de inflatic buiten beschouwing gelaten. De rekenaar kan inflatiecorrecties uitvoeren door de geaccumulecrde Nederlandse consumemenindexstijging van 14,4\% tussen 1990 en 1995 te verdisconteren.

De Koninklijke Nederlandse Petroleum Maatschappij, zoals de Nederlandse tak van de Shell-groep formeel heet, presenteert de resultaten in Britse ponden. In de hoofdtekst zijn deze omgerekend in guldens volgens de inkoopkners van 2.70 gulden van maandag 9 december 1996 . 
Natuurlijk is het bedrijfsresultaat geen zuivere winst. Bij voorbeeld belastingen en investeringen (afschrijvingen) gaan nog ten koste van de uiteindelijke winst. Ook kan de daling van de werkgelegenheid binnen de ondernemingen (deels) worden gecompenseerd via een toeneming van het aantal banen buiten de\%e bedrijven als gevolg van uitbesteding. De navolgende macro-economische analyse latat overigens zien dat deze externe banengroei niet toereikend is. Ten slotte moet diteraard worden opgemerkt dat veel van de werkgelegenheid van de vijf grote ondernemingen in het buitenlanel is gelocaliseerd.

7 Een diesrede, zeker indien uitgesproken vanat een kansel, leent xich witstekend voor een gezonde dosis demagogie. Het is niet mogelijk binnen het bestek van een half uur spreektijd alle muanceringen te laten doorklinken. Dat gebeurt hier en daar in voetnoten. Waar het in de hoofdtekst om gaat, is het communiceren van de hoofuboodschap.

8 lemand wordt als werkend geregistreerd zodra hij of zij is angesteld voor meer dan 11 uren per week.

9 Hierbij moet nog de kanttekening worden geplaatst dat degenen die wel betaald werk zouden willen doen maar zich niet als werkzoekend laten registreren, buiten de statistieken blijven.

10) Het is nict onwaarschijnlijk dat in termen van het bruto binnenlands product per gewerkt uur de\%: productiviteitstijging nog opvallender is, omelat in dezelfde periode het aantal deeltijdbanen is toegenomen.

11 Ik begeef mij niet in de zinloze discussie over wat armoede in het rijke Westen precies is. Natuurlijk is het armoedegevoel relatief. Daar gaat het hier om.

12 Goeroes verdienen niet slecht. Tom Peters komt alleen opdagen voor een vergoeding van 50 duizend gulden per sessie INRC Handelsblind van donderdag 5 december (!) 1996: 21|. Daar steekt mijn dagtarief - helaas - wat schril bij af.

13 De volgende vijf publicaties geven een indruk van deze empirische onderzoeklijn: (i) Ciska Bosman (1997) Tratditunal and untraditiomal determinams of business success: an empirical insessigation of organizational change. mantagement capital and firm performance in the Dutch athertising industry in 1984-1994 (Maastricht: Universitaire Pers Maastricht); (ii) Christophe Boone. Bert De Brabander en Arjen van Witteloostuijn (1996) CEO locus of control and small firm performance: an integrative framework and empirical test. Journal of Management Sucios (33: 667-699); (iii) Christophe Boone en Arjen van Witteloostuijn (1996) Industry competition and firm human capital. Small Business Fonomics (8: 347-364): (iv) Hans Pennings, Kyungnook Lee en Arjen van Witceloostuijn (1996) Intangible resources and firm mortality: a study of professional services firms (Philadelphia: Wharton Business School); en

(v) Arjen van Witteloostuijn, Christophe Boone, Ad van fterson, René Olic en Rob van Well (1997) Van couramier tor strateeg: fo invloed van matht in 


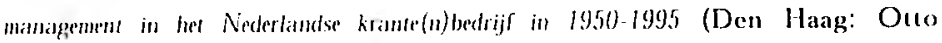
Cramwinkel). Een wiskundig-theoretische exercitie die de contraproductiviteit van afslanking illustreert, is te vinden in Arjen van Witteloostuijn (1997) Bricging behavioral and economic theories of decline: organizational inertia. strategic competition and chronic failure, Mamigemem Sciemer (43: in druk).

14 Een andere schaduwzijde van cen op Angelsaksische leest geschocid beurssysteem is een overacticve acquisitiemarkt. De ene acquisitie- en fusiegolf volgt op de andere. terwijl wetenschappelijk onderzoek keer op keer heeft aangetoond slat acquisities en fusies veel vaker hiel dan wel succesvol blijken (zie hierover bij voorbeeld Menno Tamminga in hel NRC Handelsblad van 5 november 1996: 15). Sarah Anderson en John Kavanagh (zie het NRC Handelsblad van zaterd: 26 oktober 1996: 9) geven een pregnante analyse van de nadelige effecten ban deze toenemende concentratie in het Amerikaanse en mondiale bedrijfsleven. Een bevinding is dat de omzet van de 200 grootste onderneningen in de wereld een kwart van de totale economische activiteiten in de wereld vertegenwoordigen, terwijl $\not i j$ slechts 0.75 procent (bijna 19 miljoen werknemers) van de mondiale werkgelegenheid verschaffen. En deze wanverhouding wordt alleen maar erger: "In deze tijd van automatisering en personeelsinkrimping verlogen grote ondernemingen hun winst door personecl te ontslaan, niet door mensen aan te nemen". De winsten van de betrokken ondernemingen zijn met 75 procent gestegen in de periode 1990 tot en met 1995. Kortom: de duale ontwikkeling in Nederland is alles behalve unick, maar vormt de afspiegeling van een mondiale trend. Het betoog in de hoofdtekst beperkt zich overigens gemakshalve tot de Nederlandse context.

Door saneringen getroffen managers weten vaker een nieuwe baan te bemachtigen. Daarnaast profiteren juist leidinggevenden van de forerende gouden-handdrukkencultuur, zoals ook de overheid de laatste tijl met regelmaat heeft mogen ondervinden.

16 Een zevende utopie is bij voorbeeld dat de wereldgemeenschap overgaat tot krachtige samenwerking met het oogmerk de kecrzijde van de mondialiseriug van concurrentie te verzachten. Deze zevende utopie kent een lange en weinig optimistisch stemmende historie.

17 In de economische wetenschappen bestaat een lange traditie in het schrijven van utopieën. Door in de voetsporen van Leon Walras te treden heeft bij voorbeeld Gerard Debreu de Nobelprijs gewonnen met een ocuvre dat bestaat uit wiskundige modellen van perfecte cconomicën.

18 Deze gedachtengang impliceert overigens ook dat deregulering en privatisering niet per definitie wenselijk zijn. De huidige discussie rond de privatisering van de sociale zekerheid en ziekenfondsen illustreert dit bij voorbeeld ten overvlocde. 